\title{
Expression of cell wall related genes in basal and ear internodes of silking brown-midrib-3, caffeic acid O-methyltransferase (COMT) down-regulated, and normal maize plants Sabine Guillaumie ${ }^{1,2}$, Deborah Goffner ${ }^{2}$, Odile Barbier ${ }^{2}$, Jean- Pierre Martinant $^{3}$, Magalie Pichon ${ }^{2}$ and Yves Barrière* ${ }^{*}$
}

Address: ${ }^{1}$ INRA, Unité de Génétique et d'Amélioration des Plantes Fourragères, BP6, F-86600 Lusignan, France, ${ }^{2}$ UPS CNRS UMR 5546, Chemin de Borde Rouge, F-31326 Castanet-Tolosan, France and ${ }^{3}$ Biogemma, ZI du Brézet, 8, rue des frères Lumière, F-63028 Clermont-Ferrand, France

Email: Sabine Guillaumie - sabine.guillaumie@bordeaux.inra.fr; Deborah Goffner - goffner@scsv.ups-tlse.fr; Odile Barbier - barbier@scsv.upstlse.fr; Jean-Pierre Martinant - jean-pierre.martinant@limagrain.com; Magalie Pichon - pichon@scsv.ups-tlse.fr;

Yves Barrière* - yves.barriere@lusignan.inra.fr

* Corresponding author

Published: 26 June 2008

BMC Plant Biology 2008, 8:7| doi:|0.|I86/|47|-2229-8-7|
Received: 6 March 2008

Accepted: 26 June 2008

This article is available from: http://www.biomedcentral.com/I47I-2229/8/7I

(c) 2008 Guillaumie et al; licensee BioMed Central Ltd.

This is an Open Access article distributed under the terms of the Creative Commons Attribution License (http://creativecommons.org/licenses/by/2.0), which permits unrestricted use, distribution, and reproduction in any medium, provided the original work is properly cited.

\begin{abstract}
Background: Silage maize is a major forage and energy resource for cattle feeding, and several studies have shown that lignin content and structure are the determining factors in forage maize feeding value. In maize, four natural brown-midrib mutants have modified lignin content, lignin structure and cell wall digestibility. The greatest lignin reduction and the highest cell wall digestibility were observed in the brown-midrib-3 (bm3) mutant, which is disrupted in the caffeic acid $O$-methyltransferase (COMT) gene.

Results: Expression of cell wall related genes was investigated in basal and ear internodes of normal, COMT antisens (AS225), and bm3 maize plants of the INRA F2 line. A cell wall macro-array was developed with 65 I gene specific tags of genes specifically involved in cell wall biogenesis. When comparing basal (older lignifying) and ear (younger lignifying) internodes of the normal line, all genes known to be involved in constitutive monolignol biosynthesis had a higher expression in younger ear internodes. The expression of the COMT gene was heavily reduced, especially in the younger lignifying tissues of the ear internode. Despite the fact that AS225 transgene expression was driven only in sclerenchyma tissues, COMT expression was also heavily reduced in AS225 ear and basal internodes. COMT disruption or down-regulation led to differential expressions of a few lignin pathway genes, which were all over-expressed, except for a phenylalanine ammonia-lyase gene. More unexpectedly, several transcription factor genes, cell signaling genes, transport and detoxification genes, genes involved in cell wall carbohydrate metabolism and genes encoding cell wall proteins, were differentially expressed, and mostly over-expressed, in COMT-deficient plants.
\end{abstract}

Conclusion: Differential gene expressions in COMT-deficient plants highlighted a probable disturbance in cell wall assembly. In addition, the gene expressions suggested modified chronology of the different events leading to cell expansion and lignification with consequences far beyond the phenylpropanoid metabolism. The reduced availability of monolignols and S units in bm3 or AS225 plants led to plants also differing in cell wall carbohydrate, and probably protein, composition. Thus, the deficiency in a key-enzyme of the lignin pathway had correlative effects on the whole cell wall metabolism. Furthermore, the observed differential expression between $b m 3$ and normal plants indicated the possible involvement in the maize lignin pathway of genes which up until now have not been considered to play this role. 


\section{Background}

Since shortly after its introduction into Europe, maize has been recognized to be an excellent forage plant and is now the most important annual forage crop in Northern Europe. Despite the fact that maize silage provides roughage with high energy content, large genetic variations in cell wall digestibility have been established between maize genotypes [1]. The lignified grass cell wall is a composite material with cellulose microfibrils, an amorphous matrix consisting of hemicelluloses (mainly glucuronoarabinoxylans) with very little pectins, and phenolics. Phenolics are comprised of lignins, which are essential for the structural integrity of tissues and impart hydrophobicity to vascular elements. They also are comprised of cell wall-linked p-coumaric (pCA) ferulic, and diferulic acid derivatives. Lignins are the only cell wall component resistant to micro-organism degradation. Hence, lignin content is a primary factor involved in cell wall digestibility variation. In addition, lignin variable structure and the intensity of cross-linkages between cell wall components also have variable depressive effects on cell wall carbohydrate degradation by microorganisms in the cow rumen. [2-4]. The lignin pathway begins after the shikimate pathway with the deamination of L-phenylalanine into cinnamic acid. Successive steps including hydroxylation and methylation on the aromatic ring lead to production of three monolignols ( $p$-hydroxyphenyl, coniferyl, and syringyl alcohols). The latter are polymerized into lignins, giving rise to the three $p$-hydroxyphenyl $(\mathrm{H})$, guaiacyl $(\mathrm{G})$ and syringyl (S) monomeric units. In the maize lignin pathway, caffeic acid O-methyltransferase (COMT) is specifically involved in methylation of 5-hydroxy-coniferaldehyde into sinapaldehyde.

Besides the reddish brown pigmentation of the leaf midrib and stalk pith associated with lignified tissues, brownmidrib $(\mathrm{bm})$ mutants of maize were early distinguished by their lower lignin content and modified lignin structure [5-7]. Among the four non-allelic bm mutants, bm 3 exhibits the strongest phenotype and was early considered to be a powerful model in cell wall digestibility improvement and lignification studies [8-12]. Compared with normal hybrids, cell wall digestibility of isogenic bm3 genotypes was increased by about 9 percentage points [1]. Correlatively, and based on several experiments with lactating cows [13-15], the intake of bm3 silage by dairy cows was always higher than the intake of normal silage ( 1.5 to 2.5 kg DM per day). A higher milk yield of cows fed bm3 hybrids was also reported in most experiments. Every time this trait was recorded, an increase in body weight was also observed in cattle fed with bm3 silage. However, the bm3 mutation has adverse effects on agronomic traits such as lower biomass yield and higher susceptibility to lodging and diseases, especially in early maize genetic back- grounds. As a consequence, only a few late maize hybrids are available for farmers on the US market [16-18].

Since the precursory studies done from 1960 to 1970 , extensive research has been devoted to maize $b m 3$ plants in order to establish the key determining factors in their higher feeding value, with an in- depth description of their specific lignification patterns [2,19-21]. The lignin content of maize bm 3 mutant plants is reduced by about 25 to $40 \%$, with a partly correlative reduced content of pCA esters by about $50 \%$. In the sixties, Kuc et al. [7] established that the frequency of $S$ units was reduced in bm3 mutants, and they suspected the occurrence of additional not yet detected units. The thioacidolysis S/G ratio was shown to be reduced from $1.2-1.5$ in normal plants to $0.2-0.5$ in $b m 3$ plants, and the additional units in lignins were identified as 5-hydroxyguaiacyl (5-OH-G) units [22]. The reduction in pCA esters thus appeared consistent with the preferential acylation of $S$ units by $p$-coumaric acid [23-25]. The content of alkali-releasable FA in bm3 mature plants was not altered $[2,26]$. In younger plants, Marita et al. [27] obtained a greater amount of FA esterified to arabinoxylans in the bm3 cell walls. However, similar cross-linking between arabinoxylans (total FA dimers) was obtained.

A nearly null COMT activity has been shown in maize $b m 3$ plants [28-30]. Vignols et al. [29] and Morrow et al. [30] later established that $b m 3$ mutants had an altered exon 2 of the COMT gene, with different events likely corresponding to different insertions/excisions of a transposable element. Down-regulation of COMT in maize gave plants with similar lignin patterns as observed in bm3 mutants [31,32]. In Arabidopsis, a lignin devoid of S units was observed due to a mutation in the gene encoding ferulate 5-hydroxylase (F5H) [33,34], while the Arabidopsis "bm3" mutant lacking the following COMT step in the pathway only had a reduced S content [35]. Only one COMT sequence is described in databases for maize, and a unique COMT in maize would seem to be the most probable hypothesis to date. The presence, even clearly reduced, of $\mathrm{S}$ units in $b m 3$ lignins then raises a question about a substitutive pathway, and/or a substitutive OMT. In contrast to $S$ unit content, normal ferulic acid content was observed in bm3 or AS225 plants, showing that COMT is very likely not involved in its biosynthesis. Ferulic acid biosynthesis in maize is still not clearly understood and different putative pathways have been discussed recently [36]. Based on the data of Nair et al. [37] with the ref1 mutant of Arabidopsis, ferulic acid could be produced in maize beyond the monolignol pathway. Ferulic acid could be derived from oxidation of the corresponding aldehyde, rather than acting as a precursor of this aldehyde. 
In contrast to phenolic compounds, only a few changes in cell wall carbohydrate characteristics were observed in $b m 3$ plants. The cellulose content of $b m 3$ maize was nearly the same as in normal plants, and the hemicellulose content was reported to be slightly or significantly higher in $b m 3$ plants [20]. The composition of hemicelluloses also appeared to be little modified in $\mathrm{bm} 3$ plants. In plant stalks with just emerging tassels, Marita et al. [27,38] found a higher xylan content (as estimated by xylose) in bm3 mutants. Similarly, the xylan substitution with arabinose was a little lower in $b m 3$ maize than in normal maize. A minor but significant decrease was also observed for rhamnose in $b m 3$ plants [27].

Little data is available on histological comparisons of normal and $b m 3$ tissues. Based on scanning electron microscopy observations [39], the sclerenchyma of bm3 stem tissues appeared less dense, less rigid and less thick, with larger cell lumens than in normal plants. Moreover, the parenchyma of $b m 3$ plants was more rapidly degraded in rumen fluid and the sclerenchyma walls were highly degraded and considerably thinned in $b m 3$ plants. In contrast, the sclerenchyma of normal plants was little changed even after 72 hours of incubation in the rumen fluid.

In a study devoted to a comparison of 144 cell wall gene expressions in 20-day-old normal and bm plants [40], only seven genes were differentially expressed in the $b m 3$ mutant. The seven genes were all over-expressed except for the disrupted COMT. Gene expression was also investigated in young stems of three normal and $b m 3$ lines. The latter were harvested 5 and 7 weeks after germination, with a micro-array containing nearly 12,000 ESTs [41,42]. Out of 865 candidate ESTs putatively involved in cell wall digestibility variation, only 53 were differentially expressed between $b m 3$ and normal isogenic plants.

The first objective of the present study was to investigate variations in expression of cell wall related genes in older and more lignified tissues of $b m 3$, COMT down-regulated, and normal silking maize plants. Investigations were based on ear (young) and basal (old) internodes which differ in their physiological maturity. A second objective was to relate variation in gene expression to the previously described modifications in cell wall components, lignin content and structure of $b m 3$ and COMT down-regulated plants. A third objective was to find new factors involved in maize cell wall lignification and assembly, in order to further improve forage maize feeding value. Expression studies were based on a macro-array specifically devoted to cell wall and lignification topics developed in CNRSUPS Toulouse for such investigations [43].

\section{Results and Discussion \\ Lignin pathway gene expression in normal F2 basal and ear internodes of maize}

Older and younger lignification stages were compared in basal and ear internodes of the F2 normal line. All genes known to be involved in constitutive monolignol biosynthesis had a higher expression in younger ear internodes, indicating their higher lignification activity, than in older basal internodes (data not shown). An expression at least three times higher was thus observed for genes encoding phenylalanine ammonia-lyases (PAL), cinnamate 4hydroxylases $(\mathrm{C} 4 \mathrm{H})$, 4-coumarate:CoA ligases (4CL), caffeoyl-CoA O-methyltransferases (CCoAOMT), F5H, COMT, cinnamoyl-CoA reductases (CCR), cinnamyl and sinapyl alcohol dehydrogenases (CAD and SAD). Expressions of hydroxycinnamoyl transferases (HCT) and $p$-coumaroyl-shikimate/quinate 3'-hydroxylases $\left(\mathrm{C}^{\prime} \mathrm{H}\right)$ genes were low, raising the possibility of other still unknown homolog genes involved in the pathway. Among the five maize CCOAOMT genes shown to be expressed in maize by Guillaumie et al. [43], the most expressed genes were CCOAOMT5 and CCOAOMT3 in ear and basal internodes, respectively. Previously described CCoAOMT2 [44] was the second most expressed gene in younger internodes and in older ones. Laccase genes were more expressed than peroxidase genes, and more expressed in older internodes, probably confirming the involvement of laccases in monolignol polymerization. However, three peroxidases, including ZmPox2 and ZmPox3, had a reverse expression pattern and were more expressed in younger tissues. These peroxidases could be assumed to be more specifically involved in the first steps of cell wall assembly.

\section{Lignin content and cell wall digestibility in COMT under- expressed and disrupted plants}

Cell wall content was a little lower in AS225 basal internodes, which is likely related to a higher soluble carbohydrate content in this line. Lignin content, estimated as Klason lignin [45] in the cell wall part was reduced by 45 $\%$ in both F2bm3 and AS225 basal internodes, with a correlative average increase by $30 \%$ in cell wall digestibility, estimated as in vitro neutral detergent fiber (NDF) digestibility [46].

\section{Histochemical staining and lignin pattern alterations in bm3 or AS225 internodes}

At silking + 30 days stage of plant growth, histological observations showed that xylem, sclerenchyma and parenchyma between vascular bundles were lignified. Internodal transverse sections stained with Maüle reagent, which enables to distinguish between $S$ and $G$ units, showed important differences between F2, AS225 and bm3 lines (Figure 1A-C). All lignified tissues in F2 plants exhibited a red coloration, showing the presence of $S$ units, whereas in bm3 line both sclerenchyma and paren- 


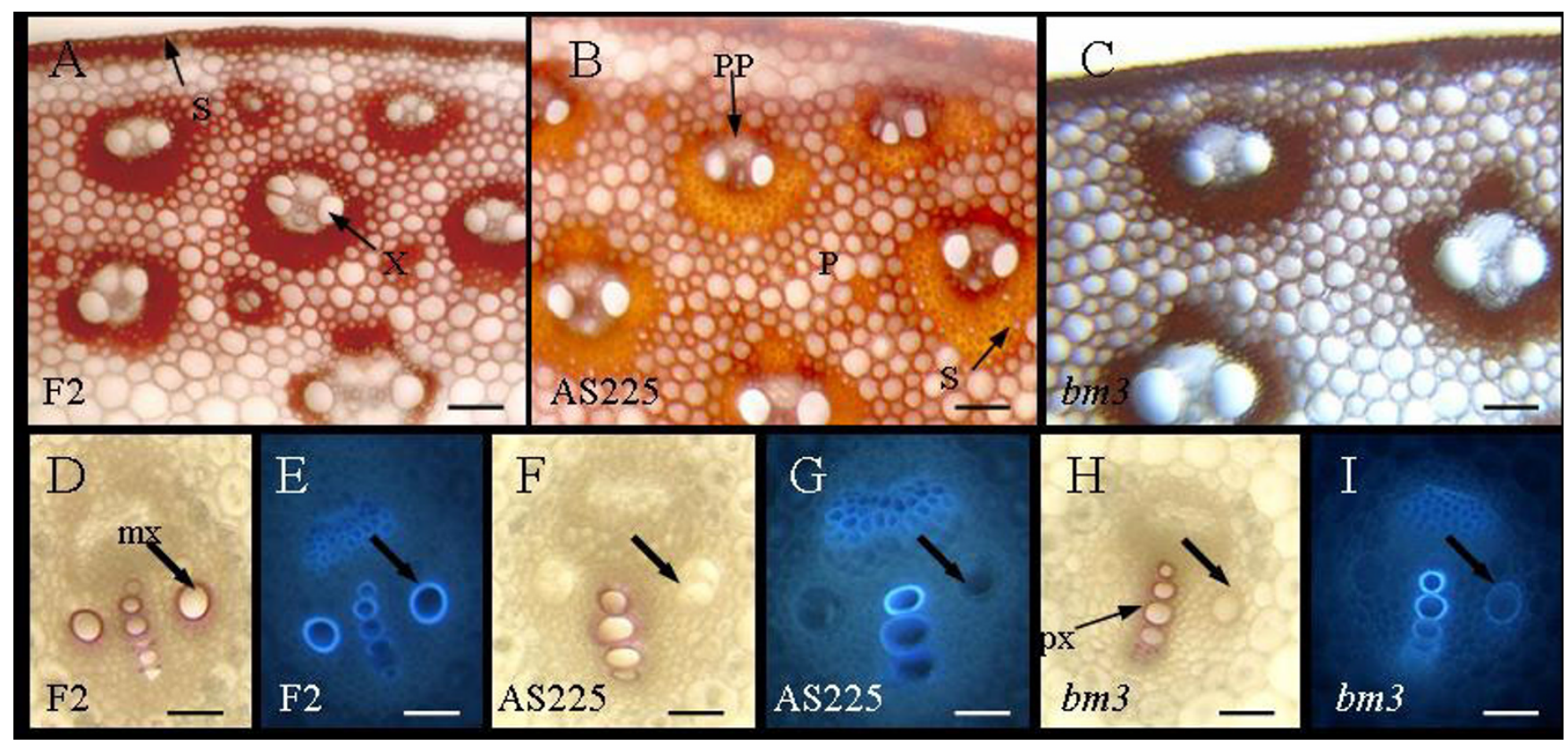

Figure I

Histochemical characterization of normal F2, AS225 and F2bm3 maize lines. F2 = normal F2 line; AS225 = COMTAS line; $b m 3=$ F2bm3 line. Light microscopy observations of transverse sections in bottom part of ear internode in silking +30 day-old plants stained with Maüle reagent (A-B). Light microscopy observations of transverse sections in bottom part of ear internode in silking plants stained with Wiesner reagent $(D, F, H)$. UV illumination of ear internode bottom part in silking plants $(E, G, I)$. Differences in coloration of lignified tissues between F2, AS225 and F2bm3 lines in the presence of Maüle reagent (AC) are visible. Metaxylem vessels of ear internode transverse sections (D-I) of AS225 and F2bm3 plants also had a modified lig-

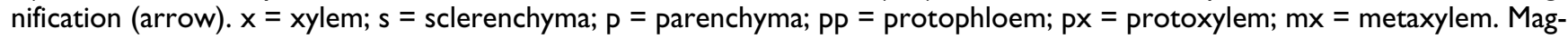
nification bar was $100 \mu \mathrm{m}(A-C)$ or $50 \mu \mathrm{m}$ (D-I).

chyma between bundles had a brown coloration, underlying an absence of $S$ units in both of these cell types. In AS225 plants, lignified parenchyma cells stained red, similar to F2 line, but sclerenchyma cells surrounding vascular bundles displayed an orangey color. This difference probably indicated a sclerenchyma-specific reduction of $S$ units in AS225 line and highlighted the fact that using Adh1 promoter directs COMT down-regulation specifically in sclerenchyma tissues [31].

At silking stage, Wiesner staining (Figure $1 \mathrm{D}, \mathrm{F}$ and $1 \mathrm{H}$ ) and UV-light (Figure 1E, G, I) observations of the bottom part of ear internode cross sections showed that protoxylem is lignified in all observed lines. Metaxylem vessels are lignified in F2 line but were only weakly lignified in bm3 plants and not lignified in AS225 plants.

\section{Lignin and phenylpropanoid pathway gene differential expression in bm3 or AS225 internodes}

The expression of the COMT gene was, as expected, heavily reduced in COMT-disrupted and down-regulated plants. In younger lignifying tissues of the ear internode, COMT expression was reduced to a nearly null value in bm3 plants. Despite transgene, was driven only in scleren- chyma tissues of AS225 plants, COMT under-expression was reduced by $80 \%$ in AS225 ear internodes (Table 1, Figure 2). COMT expression was reduced by 20-25\% in both bm3 and AS225 basal internodes (Table 1). More genes were differentially expressed in younger ear internodes than in older basal internodes. In addition, the pattern of gene deregulation was almost similar in bm3 and AS225 plants. However, a lower number of genes were differentially expressed in AS225 plants and their expressions were less modified than in bm3 plants. Disruption or down-regulation of COMT led to a differential expression of a limited number of genes related to the phenylpropanoid pathway, which were all over-expressed, except a PAL gene in bm3 plants. The small number of differentially expressed genes has also been observed in younger growing bm3 plantlets [40], illustrating a possible weak apparent co-regulation of lignin pathway genes at these developmental stages. Contrary results were obtained by Shi et al. [41] in a F2/F2bm3 comparison, with differentially expressed lignin pathway genes most often underexpressed in bm3 plants, except for two cytochrome P450 98A1 (C3'H) over-expressed genes. Observed differences could be related to variable stages of sampling and crop- 
Table I: Phenylpropanoid and lignin pathway genes differentially expressed in maize F2, F2bm3 and AS225 basal and ear internodes at silking stage.

\begin{tabular}{|c|c|c|c|c|c|c|c|c|}
\hline \multirow[b]{2}{*}{$\begin{array}{l}\text { Maize phenylpropanoid and lignin pathway } \\
\text { related genes }\end{array}$} & \multirow[t]{2}{*}{ Contig } & \multirow[t]{2}{*}{ mRNA } & \multicolumn{3}{|c|}{ Basal internode } & \multicolumn{3}{|c|}{ Ear internode } \\
\hline & & & F2 & $\mathrm{F} 2 \mathrm{bm} 3 / \mathrm{F} 2$ & AS225/F2 & F2 & $\mathrm{F} 2 \mathrm{bm} 3 / \mathrm{F} 2$ & AS225/F2 \\
\hline $\begin{array}{l}\text { Phenylalanine/Tyrosine ammonia-lyase (PAL/TAL, } \\
\text { MZPAL) }\end{array}$ & 2161072.2 .1 & L77912 & 38154 & 0.50 & 0.92 & 187353 & 0.22 & 0.66 \\
\hline Cinnamate 4-hydroxylase $2(\mathrm{C} 4 \mathrm{H} 2)$ & - & CF647652 & 30820 & 1.71 & 1.28 & 19988 & 3.20 & 1.80 \\
\hline 4-Coumarate:CoA ligase 2 (4CL2) & - & - & 22694 & 1.59 & 1.39 & $214 \mid 4$ & 2.36 & 1.22 \\
\hline Caffeic acid O-methyltransferase (COMT) & 2192909.2 .3 & M73235 & 39113 & 0.25 & 0.22 & 142203 & 0.05 & 0.12 \\
\hline Ferulate 5-hydroxylase $(\mathrm{F} 5 \mathrm{H})$ & - & DR966008 & 13754 & 3.13 & 2.34 & 45662 & 0.99 & 0.54 \\
\hline Caffeoyl CoA O-methyltransferase (CCoAOMT3) & $259 \mid 258.2 .1$ & AYI04670 & 32846 & 1.87 & 1.97 & 23740 & 3.18 & 2.45 \\
\hline Caffeoyl-CoA O-methyltransferase (CCoAOMT4) & 2943966.2 .1 & Al855419 & 14245 & 1.98 & 1.84 & 13947 & 2.38 & 1.54 \\
\hline Peroxidase (ZmPox2) & 2619325.2 .1 & AJ40I 275 & 20634 & 2.60 & 1.58 & 10903 & 4.02 & 2.66 \\
\hline Peroxidase (4th zinnia DV0I75I 2 ortholog) & $2763|2| .2 .1$ & AYII 0228 & $1508 \mid$ & 1.75 & 1.27 & 10476 & 2.63 & 1.73 \\
\hline Laccase (Poplar lac3 Ist ortholog) & 8616263.2 .1 & BG842157 & 83977 & 2.05 & 1.79 & 46998 & 3.80 & 2.79 \\
\hline Laccase (Poplar lac3 $3^{\text {rd }}$ ortholog) & 2440419.2 .1 & ВT019237 & 21387 & 2.08 & 1.49 & 13702 & 2.90 & 1.85 \\
\hline $\begin{array}{l}\text { Aldehyde dehydrogenase (ALDH, ALDH22AI } \\
\text { ortholog) }\end{array}$ & 2750698.2 .1 & AYI09842 & 21185 & 2.05 & 1.38 & 13749 & 2.75 & 1.75 \\
\hline Chorismate mutase & $252 \mid 459.2 .4$ & AYI03806 & 34104 & 1.78 & 1.91 & 19436 & 3.85 & 2.45 \\
\hline Chorismate mutase/Prephenate dehydratase & 2950290.2 .1 & AY 109614 & 19357 & 2.09 & 1.54 & $|875|$ & 2.35 & 1.42 \\
\hline Chalcone flavonone isomerase ( $\mathrm{ZmCHII})$ & 3390529.2 .1 & Z22760 & 30010 & 2.79 & 1.85 & 19524 & 3.73 & 2.31 \\
\hline
\end{tabular}

Normalized expression values are given for the F2 line and values for each mutant are expressed as ratios of signal intensity compared to normal plants. Genes were considered to be significantly differentially expressed when expression ratio values were lower than 0.5 or higher than 2.0 . Values between the two thresholds are indicated in italics.

ping conditions, and to a different set of investigated genes.

Besides the under-expressed COMT gene, the "new" CCOAOMT3 and CCOAOMT4 genes were over-expressed in young ear internodes, while the two currently known

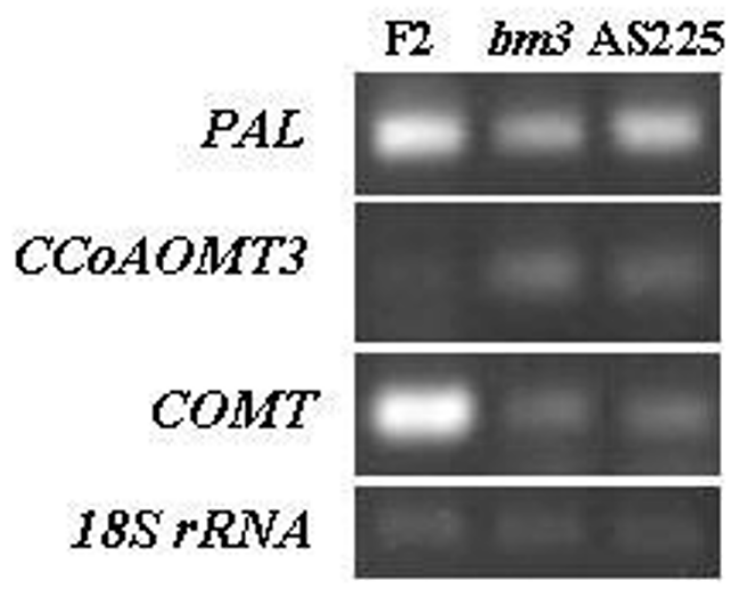

Figure 2

RT-PCR expression analysis of three genes of phenylpropanoid and lignin pathway. Transcripts of PAL (2|6|072.2.I, L779|2), CCoAOMT3 (2591258.2.I, AY 104670) and COMT (2192909.2.3 M73235) were detected by semi-quantitative RT-PCR in ear internodes from normal, bm3 and AS225 silking stage plants. I8S rRNA was used as a quantitative control.
CCOAOMT1 and CCOAOMT2 were not differentially expressed (Table 1, Figure 2). CCoAOMT enzymes have a strict affinity for CoA-ester and have no or very little affinity on corresponding acids [36,47-49]. Consequently, it could not be considered that the two CCoAOMT substitute the missing COMT activity in the biosynthesis, of about a $40 \%$ residual S content in $b m 3$ plants [2]. The missing COMT activity was probably substituted by other OMT, whether they are over-expressed or not. Plausible candidates include ZRP4-like OMT. Several ZRP4-like OMT genes were indeed shown to be significantly expressed in stalk lignifying tissue [43], and their role is likely not limited to methylation of suberin sub-unit precursors as initially described by Held et al. [50]. Moreover, two ZRP4-like OMT genes were over-expressed in $b m 3$ plantlets [40], including the AY108765 ZRP4-like OMT which also have a tendency to be over-expressed in ear internodes of $b m 3$ silking plants with a ratio equal to 1.71 . Unlike the under-expressed COMT, one F5H gene, whose encoded protein supplies COMT in its 5-hydroxy-coniferaldehyde substrate, has an increased expression in older internodes of $b m 3$ and AS225 plants. However, this is not the case in younger ear internodes.

A PAL/TAL gene, which encodes the entry enzyme of the phenylpropanoid pathway, had a greatly reduced expression in F2bm3 ear internodes and, to a lesser extent, in basal internodes. However, the expression was not reduced in AS225 internodes (Table 1, Figure 2). A low 
PAL expression was in agreement with the much lower lignin content of $b m 3$ stalk tissues. In contrast to PAL, a $\mathrm{C} 4 \mathrm{H}$ and a 4CL gene, whose encoded proteins catalyzed the following steps of the pathway, were over-expressed in $b m 3$ young internodes. Also in contrast to PAL underexpression, a chorismate mutase was over-expressed in the youngest internodes of both $b m 3$ and AS225 plants, upstream in the phenylpropanoid pathway. In the shikimic acid pathway, chorismate mutase is the enzyme which catalyzes the first committed step in phenylalanine and tyrosine biosynthesis [51,52]. This allows the intramolecular rearrangement of the enolpyruvyl chain of chorismate to produce prephenate. The chorismate mutase/prephenate dehydratase gene over-expressed in the ear internode of $b m 3$ possibly encoded a bifunctional chorismate mutase/prephenate dehydratase as observed by Fischer et al. [53], but its involvement as a precursor supplier for lignin biosynthesis is still unknown.

The ZmPox2 peroxidase gene, whose encoded protein is involved in constitutive lignification [54], had an increased expression in $b m 3$ and AS225 plants, especially in younger internodes. Simultaneously with the higher ZmPox2 expression, two laccase genes were similarly over-expressed in $b m 3$ young internodes, and one in AS225 plants. These maize laccases were close orthologs to the poplar lac3 gene, whose down-regulation in poplar induced an important alteration of xylem fiber cell walls, with an increase in soluble phenolic compounds, especially in xylem parenchyma cells [55].

According to Nair et al. [37], sinapic and probably ferulic acids in Arabidopsis derived from oxidation of the corresponding aldehydes, rather than acting as precursors of those aldehydes. A putative involvement of aldehyde dehydrogenase (ALDH) enzymes in maize ferulate biosynthesis has not yet been established. However, several ALDH genes are expressed in lignifying tissue [43] including the ALDH22A1 Arabidopsis ortholog [56,57] overexpressed in COMT deficient tissues, which was also the most expressed ALDH in normal internodes. While the lignin content of $b m 3$ maize plants was greatly reduced, their content in ferulates released after alkaline hydrolysis was not modified or slightly increased [2].

The maize chalcone flavonone isomerase ( $\mathrm{ZmCHI} 1)$, described in maize by Grotewold and Peterson [58], was over expressed in bm3 and AS225 internodes. CHI catalyzes conversion of chalcone, a yellow pigment synthesized downstream to the coumaroyl-CoA, into naringenin. $\mathrm{CHI}$ genes are regulated by MYB transcription factors [58-60], similarly to several other phenylpropanoid-related genes. Because $\mathrm{ZmCHI} 1$ gene is not involved in the lignin pathway, its over-expression could be interpreted as a possible reaction against over-availability of monolignol precursors.

\section{Differential expression of transcription or regulation factor genes in bm3 or AS225 internodes}

Several transcription or regulation factors, including one ATHB-8 HD-zip III, two Argonaute, and one Shatterproof MAD-box ortholog gene, were over-expressed in both ear and basal internodes of $b m 3$ and, to a lesser extent, AS225 silking plants (Table 2). These transcription factors were not differentially expressed in $b m 3$ plantlets. However, some of the transcription factors were under-expressed in $b m 1, b m 2$, and/or $b m 4$ plantlets [40]. Homeodomain-leucine zipper (HD-Zip) III proteins are transcription factors which belong to a class of highly related proteins characterized by their expression in (pro)-vascular tissues. ATHB-8 HD-Zip proteins are positively regulated by auxin and promote vascular cell division and differentiation towards the formation of xylem and vascular tissue $[61,62]$. Argonaute genes are required for post-transcriptional gene silencing and RNA interference, and many of the miRNA which have thus far been identified in plants are predicted to target transcription factors involved in developmental processes [63,64]. An over-expression of an Argonaute gene, as observed in bm3 and AS225 deficient COMT plants, is considered to induce a higher

Table 2: Cell-wall-related transcription and regulation factor genes differentially expressed in maize F2, F2bm3 and AS225 basal and ear internodes at silking stage.

\begin{tabular}{|c|c|c|c|c|c|c|c|c|}
\hline \multirow[b]{2}{*}{ Transcription and regulation factors } & \multirow[t]{2}{*}{ Contig } & \multirow[t]{2}{*}{ mRNA } & \multicolumn{3}{|c|}{ Basal internode } & \multicolumn{3}{|c|}{ Ear internode } \\
\hline & & & F2 & $\mathrm{F} 2 \mathrm{bm} 3 / \mathrm{F} 2$ & AS225/F2 & F2 & $\mathrm{F} 2 \mathrm{bm} 3 / \mathrm{F} 2$ & AS225/F2 \\
\hline ATHB-8 HD-zipllI & QBN2 IE06.xg.2.I & CO529337 & 16199 & 2.27 & 1.87 & 14535 & 2.88 & 1.62 \\
\hline Argonaute & 131537.2 .170 & AYI042II & 20557 & 2.67 & 1.72 & 13525 & 3.64 & 2.23 \\
\hline Argonaute & |804958.2.| & AYII0984 & 11026 & 1.88 & 1.19 & 10027 & 2.23 & 1.30 \\
\hline $\begin{array}{l}\text { SHATTERPROOF (SHPI) MADS-box } \\
\text { (ZmZAG5) }\end{array}$ & L46398.2.I & L46398 & 20258 & 2.50 & 2.07 & 15008 & 3.50 & 2.28 \\
\hline
\end{tabular}

Normalized expression values are given for the F2 line and values for each mutant are expressed as ratios of signal intensity compared to normal plants. Genes were considered to be significantly differentially expressed when expression ratio values were lower than 0.5 or higher than 2.0 . Values between the two thresholds are indicated in italics. 
repression of target genes. The simultaneous differential expression of Argonaute genes and the ATHB-8 HD-Zip gene could be related. The maize rolled leaf1 gene (rld1) indeed encodes a HD-ZIP III transcription factor, the expression of which is mediated by the miRNA Zmmir166 [65]. SHATTERPROOF (SHP1) MADS-box gene is involved, with SHP2, in lignification of valve margin cells adjacent to the dehiscence zone of Arabidopsis siliques [66]. The over-expressed maize SHP1 ortholog gene was the ZmZAG5 gene which has been described with ZmZAG3 [67,68] as an AGL6-like gene (agamous-like). Whether such a SHP maize ortholog could be involved in lignified tissue differentiation or more directly in lignification, is not yet known. However, its deregulation in $\mathrm{bm} 3$ and AS225 tissue could for the first time illustrate a relationship between this type of regulation factor and cell wall differentiation or lignification in grass plant stalks.

\section{Differential expression of genes related to auxin signaling and tissue patterning in bm3 or AS225 internodes}

Several genes related to auxin signaling, and/or probably involved in vessel set up or tissue patterning, were overexpressed in basal or ear internodes of COMT deficient plants (Table 3). This occurrence probably indicated a feedback disorganization of tissues and cell wall assembly when the activity of the key COMT enzyme was missing.

PINOID (PID) orthologous genes, of which one member was over-expressed in basal and ear $b m 3$ internodes, and in ear AS225 internodes, encode serine/threonine protein kinases. PID genes are preferentially expressed in the vascular tissue of developing organs and in xylem parenchyma cells [69], and have been shown to be positive regulators of polar auxin transport [69-71]. The Emb30 gene of Arabidopsis, whose maize ortholog is overexpressed in basal internodes of bm3 and AS225 plants, is involved in the maintenance of polar auxin transport. In addition, the lack of Emb30 protein induced an irregular and discontinuous venation, with clustered or scattered tracheary elements $[72,73]$. The Emb30 gene encodes a guanine nucleotide exchange factor (GEF) on adenosine diphosphate (ADP)-ribolysation factor GTPase (ARFGEF), which is involved in the targeted recycling of PIN1 putative auxin efflux carrier [74]. Its over-expression in bm3 and AS225 plants was likely a consequence of tissue assembly with a reduced amount of S units. In addition, one MONOPTEROS (MP) gene ortholog was overexpressed in $b m 3$ ear internodes. The MP gene of Arabidopsis encodes a transcription factor of the auxin response factor (ARF) family, which is also involved in vascular cell differentiation $[75,76]$. The Arabidopsis recessive mutant "CONTINUOUS VASCULAR RING" (COV1) has a great increase in stem vascular tissue in of inter-fascicular regions [77]. Moreover, it has been established that cov1 affects vascular patterning by a mechanism which is not auxin-dependant [77]. In addition, cov1 mutants were shown to be defective in synthesis, transport, or perception of an inhibitor. The maize COV1 ortholog overexpression in $\mathrm{bm} 3$ ear lignifying internodes thus corresponded to a higher inhibition in lignified tissue formation, possibly illustrating a feed-back effect resulting from the low availability of $S$ units.

Cucumisins are serine protease of the subtilisin family [78]. Cucumisins are involved in the general protein turnover as non-selective enzymes, but they also perform specific roles in the processing of precursor proteins to regulate growth and development by limited proteolysis [79]. The over-expressed maize cucumisin in bm3 and AS225 ear internodes was the closest ortholog to a zinnia (Zinnia elegans Jacq.) cucumisin expressed during xylogenesis [80]. Similarly, a subtilase (XSP1, At4g00230) has been identified from a xylem library of Arabidopsis [81]. The role of cucumisins in phenylpropanoid biosynthesis is still unknown. However, it is plausible that several cucumisins could function during autolysis of tracheary elements. A cucumisin gene deregulation in $b m 3$ internodes could be in agreement with the lower stiffness of $b m 3$ plant vessels.

Table 3: Cell-wall-related genes involved in auxin signaling and tissue patterning differentially expressed in maize F2, F2bm3 and AS225 basal and ear internodes at silking stage.

\begin{tabular}{|c|c|c|c|c|c|c|c|c|}
\hline \multirow[b]{2}{*}{$\begin{array}{l}\text { Auxin signaling and tissue patterning } \\
\text { related genes }\end{array}$} & \multirow[t]{2}{*}{ Contig } & \multirow[t]{2}{*}{ mRNA } & \multicolumn{3}{|c|}{ Basal internode } & \multicolumn{3}{|c|}{ Ear internode } \\
\hline & & & $\mathrm{F} 2$ & $\mathrm{~F} 2 \mathrm{bm} 3 / \mathrm{F} 2$ & AS225/F2 & $\mathrm{F} 2$ & $\mathrm{~F} 2 \mathrm{bm} 3 / \mathrm{F} 2$ & AS225/F2 \\
\hline Pinoid & 2591032.2 .1 & DR972540 & 25300 & 2.23 & 1.70 & 14555 & 3.42 & 2.12 \\
\hline Emb30 & 2750663.2 .1 & AYI07774 & 43944 & 2.76 & 2.15 & 91982 & 1.48 & 0.77 \\
\hline Monopteros & $244 \mid 276.2 .1$ & AYI09838 & 23901 & 1.96 & 2.03 & 19267 & 2.60 & 1.85 \\
\hline Covl Integral membrane protein & 3562100.2 .1 & AYII2I70 & 29982 & 1.94 & 1.51 & $|803|$ & 2.96 & 2.08 \\
\hline Cucumisin & $7297 \mid 69.2 .1$ & AY 105082 & 26913 & 1.98 & 1.51 & 13967 & 3.47 & 2.43 \\
\hline
\end{tabular}

Normalized expression values are given for the $\mathrm{F} 2$ line and values for each mutant are expressed as ratios of signal intensity compared to normal plants. Genes were considered to be significantly differentially expressed when expression ratio values were lower than 0.5 or higher than 2.0 .

Values between the two thresholds are indicated in italics. 


\section{Differential expression of transport and detoxification genes in bm3 or AS225 internodes}

Four genes involved in transport and detoxification processes were over-expressed in bm3 and/or AS225 internodes (Table 4). ATP-binding cassette (ABC) transporters are involved in different physiological functions such as cell signaling, transport of a broad range of substances across membranes and detoxification processes [82,83]. Given their ability to transport a diverse set of small molecules across membranes, and because several ABC transporters had similar expression profiles to known monolignol genes along the Arabidopsis growing stem, $\mathrm{ABC}$ transporters were assumed to be involved in the secretion of monolignols $[52,82,84]$. The maize $\mathrm{ABC}$ transporter over-expressed in internodes of maize $b m 3$ plants could thus be considered as a monolignol transporter. Based on its under-expression in bm2 plantlets, it has been assumed to be preferentially involved in coniferyl alcohol transport [40].

Maize bronze2-like genes encode glutathione S-transferases (GST). The latter are carrier proteins [85] which deliver anthocyanins from the biosynthesis site to the tonoplast membrane, where an appropriate ABC-type transporter moves the pigment into the vacuole [86]. Because several $\mathrm{ABC}$ transporters have a substrate preference for glutathione conjugates $[82,83,87,88]$, a coupled activity could be assumed between the two over-expressed ZmGST17 and ZmGST22 and the over-expressed ABC transporter. The much reduced COMT activity and S unit formation could induce the accumulation of phenolic compounds that have to be delivered into the vacuole as a detoxification process.

Plant glucosyltransferases belong to a multigene family, which are likely differentially regulated in different biosynthesis pathways and in response to a range of environmental stimuli. Glucosyltransferases have relative substrate specificity because of their extended plasticity towards metabolites of related structure [89]. They are involved in the biosynthesis of secondary plant metabolites and metabolization of xenobiotics. They are known in particular to have activity on both flavonoids and $p$ hydroxycinnamate derivatives. In addition, a grapevine UDP-glucose:flavonoid 3-O-glucosyltransferase, has been shown to be homolog to the maize bz1 encoded protein [90]. The role of the protein encoded by the differentially expressed UDP-glucosyltransferase-like gene is still unknown, but it could possibly be involved in detoxification and/or transport processes.

The role of nodulin MtN21-like genes is not yet understood, but the presence of seven transmembrane domains and structural homologies with bacterial multidrug exporters might suggest a role in a transport function. The maize nodulin MtN21-like gene over-expressed in bm3 and/or AS225 internodes was found to be orthologous to a zinnia nodulin MtN21-like gene expressed during xylogenesis. Consequently, the maize nodulin MtN21-like gene is probably involved in transport of a component related to vascular tissue assembly.

\section{Differential expression of cell wall associated protein genes in bm3 or AS225 internodes}

Several arabinogalactan proteins (AGP) and AGP-like proteins, which belong to a class of hydroxyproline-rich glycoproteins (HRGP), have been shown to be involved in plant xylogenesis [91-93]. Some of these proteins were thus highly preferentially expressed in differentiating xylem compared with phloem $[93,94]$. Out of the four genes encoding cell wall proteins which were differentially expressed in bm3 or AS225 internodes (Table 5), ZmRCP1 and ZmRCP2 showed especially high overexpression ratios (up to five times higher) in ear internodes. The large differential expression values in COMT deficient plants likely indicate that these AGP genes are relevant targets in understanding maize cell wall assembly.

Table 4: Cell-wall-related genes involved in transport and detoxification processes differentially expressed in F2, F2bm3 and AS225 basal and ear internodes at silking stage.

\begin{tabular}{|c|c|c|c|c|c|c|c|c|}
\hline \multirow[b]{2}{*}{ Transport and detoxification process genes } & \multirow[t]{2}{*}{ Contig } & \multirow[t]{2}{*}{ mRNA } & \multicolumn{3}{|c|}{ Basal internode } & \multicolumn{3}{|c|}{ Ear internode } \\
\hline & & & F2 & $\mathrm{F} 2 \mathrm{bm} 3 / \mathrm{F} 2$ & AS225/F2 & F2 & $\mathrm{F} 2 \mathrm{bm} \mathrm{3/F2}$ & AS225/F2 \\
\hline$A B C$ transporter & 3024030.2 .1 & DT653269 & 18994 & 2.35 & 1.81 & 13193 & 3.38 & 2.11 \\
\hline $\begin{array}{l}\text { Glutathione S-transferase II (ZmGSTI7. Bronze2 } \\
\text { like) }\end{array}$ & 3829517.2 .1 & AF244682 & 36756 & 2.43 & 1.74 & 16243 & 4.91 & 2.50 \\
\hline $\begin{array}{l}\text { Glutathione S-transferase III (ZmGST22. Bronze2 } \\
\text { like) }\end{array}$ & $244 \mid 327.2 .1$ & AF244687 & 19055 & 1.75 & 2.32 & 20836 & 2.76 & 2.61 \\
\hline UDP-glucosyltransferase like & 3748389.2 .1 & CG357903 & 83751 & 2.23 & 1.96 & 64132 & 2.80 & 1.91 \\
\hline MtN2I Nodulin-like protein & 3203235.2 .1 & CO529888 & 18082 & 2.21 & 1.89 & 11373 & 3.24 & 2.31 \\
\hline
\end{tabular}

Normalized expression values are given for the F2 line and values for each mutant are expressed as ratios of signal intensity compared to normal plants. Genes were considered to be significantly differentially expressed when expression ratio values were lower than 0.5 or higher than 2.0 .

Values between the two thresholds are indicated in italics. 
Table 5: Cell-wall associated protein genes differentially expressed in maize F2, F2bm3 and AS225 basal and ear internodes at silking stage.

\begin{tabular}{|c|c|c|c|c|c|c|c|c|}
\hline \multirow[b]{2}{*}{ Cell-wall associated proteins } & \multirow[t]{2}{*}{ Contig } & \multirow[t]{2}{*}{ mRNA } & \multicolumn{3}{|c|}{ Basal internode } & \multicolumn{3}{|c|}{ Ear internode } \\
\hline & & & $\mathrm{F} 2$ & $\mathrm{~F} 2 \mathrm{bm} 3 / \mathrm{F} 2$ & AS225/F2 & F2 & $\mathrm{F} 2 \mathrm{bm} 3 / \mathrm{F} 2$ & AS225/F2 \\
\hline Arabinogalactan protein (AGP, ZmRCPI) & AB02II75.2.I & AB02II75 & 49374 & 2.26 & 2.42 & $2074 \mid$ & 5.49 & 4.01 \\
\hline Arabinogalactan protein (AGP, ZmRCP2) & $\mathrm{AB} 021176.2 .1$ & $A B 021176$ & 41219 & 2.34 & 1.62 & 17816 & 4.76 & 3.20 \\
\hline Glycine rich protein (GRP) & 1716296.2 .7 & BT018002 & 161370 & 2.35 & 0.44 & 223451 & 2.53 & 0.42 \\
\hline Proline rich protein (PRP) & $13 \mid 537.2 .203$ & AY 105945 & 4829 & 1.40 & 0.80 & 28975 & 0.20 & 1.33 \\
\hline
\end{tabular}

Normalized expression values are given for the $\mathrm{F} 2$ line and values for each mutant are expressed as ratios of signal intensity compared to normal plants. Genes were considered to be significantly differentially expressed when expression ratio values were lower than 0.5 or higher than 2.0 .

Values between the two thresholds are indicated in italics.

One glycine-rich protein (GRP) was the only investigated gene with an over-expression in $b m 3$ internodes and an under-expression in AS225 internodes. This significant interaction could be related to the lack of complete isogenicity of F2 and AS225 genetic backgrounds, but also to the fact that COMT down-regulation in AS225 was directed specifically in sclerenchyma tissues. GRP genes encode a group of cell wall structural proteins which are particularly expressed in xylem tissues $[95,96]$. The differentially expressed GRP gene is the closest ortholog of the rice Osgrp-2 gene (AF010580) which possesses sequence elements conferring vascular-specific expression [97].

The differentially expressed proline rich protein (PRP) was one of the rare genes significantly under-expressed in COMT-deficient ear internodes. PRP are considered to be structural components of the cell wall and are abundant in fibers and xylem [98]. Vignols et al. [99] have thus described the maize ZmPRP, which is expressed in vascular tissue, mainly in cells related to xylem development, but not in phloem cells. However, the differentially expressed PRP and ZmPRP are very different genes, with only $15 \%$ identity. The protein encoded by the underexpressed PRP gene is a basic PRP, with $26 \%$ of proline amino acid and a peptide signal allowing protein secretion in the cell wall. It also presents a six-times repeated PPVTGPP(KG)(P)VTYPP motif, which is different from the classic PRP motif [PPVX $(\mathrm{K} / \mathrm{T})$, with $\mathrm{X}$ being $\mathrm{Y}, \mathrm{H}$, or $\mathrm{E}]$. This PRP, which is probably involved in cell wall formation, appeared to be an original and possibly new type of cell wall PRP.

\section{Differential expression of genes involved in nucleotide sugar interconversion and cell wall carbohydrate metabolism in bm3 or AS225 internodes}

The nucleotide sugar interconversion pathway comprises a set of enzymatic reactions by which plants synthesize activated monosaccharides as precursor elements of cell wall polysaccharides [100]. Nucleotide sugars are thus substrates used for the elongation of carbohydrate chains by UDP-glycosyltransferase $[101,102]$. Cellulose is syn- thesized by an enzyme complex associated with the plasma membrane, using UDP-D-glucose as a precursor. While UDP-D-glucose is also a precursor of hemicelluloses, hemicellulose polysaccharides are formed in the Golgi apparatus and are exported to the external surface of the membrane in Golgi vesicles [103].

Seven genes of the nucleotide sugar interconversion pathway, which belonged to five multigene families, were over-expressed in bm3 and/or AS225 plants (Table 6). Sucrose synthases catalyze a reversible reaction giving UDP-D-glucose from sucrose and uridine diphosphate (UDP). UDP-D-glucose dehydrogenases convert UDP-Dglucose into UDP-D-glucuronic acid (UDP-D-GlcA). UDPD-GlcA is afterwards the substrate of UDP-D-GlcA decarboxylases, giving UDP-D-xylose, which is then converted into UDP-L-arabinose in a reversible reaction catalyzed by UDP-D-xylose 4-epimerases [102]. GDP-D-mannose 4,6dehydratase catalyzes the irreversible conversion of GDPD-mannose into 4-keto-6-deoxy-GDP-D-mannose, then allowing the synthesis of GDP-fucose [100,102]. In plant stalks with just emerging tassels, a decrease in mannose content has been observed in bm3 plants [27], which could be related to over-expression of GDP-D-mannose 4,6-dehydratase.

Several genes involved in cell wall modification during cell growth and vascular element formation were differentially expressed between normal and COMT deficient plants (Table 6). Expansins are involved in the disruption of hydrogen bounds between cellulose microfibrils and cross-linking glycans in the cell wall. At least five different expansin genes are expressed in differentiating tracheary elements of zinnia. These genes were associated with the intrusive growth of protoxylem and with the differentiation of mesophyll cells into tracheary elements [80]. Xyloglucan endotransglycolase/hydrolases (XTH) and glucanases modify the structure of the cell wall so that it becomes more responsive to primary wall-loosening events $[104,105]$. Xyloglucan binds non-covalently to cellulose, coating and cross-linking adjacent cellulose micro- 
Table 6: Nucleotide sugar and cell-wall carbohydrate metabolism genes differentially expressed in maize F2, F2bm3 and AS225 basal and ear internodes at silking stage.

\begin{tabular}{|c|c|c|c|c|c|c|c|c|}
\hline \multirow[b]{2}{*}{$\begin{array}{l}\text { Nucleotide sugar and cell wall } \\
\text { carbohydrates }\end{array}$} & \multirow[t]{2}{*}{ Contig } & \multirow[t]{2}{*}{ mRNA } & \multicolumn{3}{|c|}{ Basal internode } & \multicolumn{3}{|c|}{ Ear internode } \\
\hline & & & F2 & $\mathrm{F} 2 \mathrm{bm} 3 / \mathrm{F} 2$ & AS225/F2 & F2 & $\mathrm{F} 2 \mathrm{bm} 3 / \mathrm{F} 2$ & AS225/F2 \\
\hline Sucrose synthase (ZmSPS5a) & 3748394.2 .2 & M97550 & 66356 & 1.08 & 0.86 & $3645 I$ & 2.17 & 1.50 \\
\hline Sucrose synthase (ZmSusl) & 131537.2 .202 & L22296 & 62970 & 1.0 & 1.38 & 92642 & 0.96 & 2.10 \\
\hline UDP-D-glucose dehydrogenase & 2750995.2 .1 & AYI03689 & 35321 & 2.18 & 1.56 & I7554 & 3.83 & 2.49 \\
\hline UDP-D-glucose dehydrogenase & 2405245.2 .2 & AF457980 & 34777 & 1.95 & 1.85 & 27367 & 2.54 & 2.48 \\
\hline $\begin{array}{l}\text { UDP-D-glucuronic acid decarboxylase (AtUXS2 } \\
\text { ortholog) }\end{array}$ & 3042304.2 .1 & AYI06346 & 14116 & 5.62 & 2.53 & 12568 & 1.59 & 4.34 \\
\hline UDP-D-xylose 4-epimerase (mur4 ortholog) & 3070703.2 .1 & AY 106136 & 24293 & 2.33 & 1.32 & 27434 & 3.68 & 1.33 \\
\hline $\begin{array}{l}\text { GDP-D-mannose 4.6-dehydratase (murl } \\
\text { ortholog) }\end{array}$ & 2621786.2 .1 & AFI 34575 & 62635 & 2.94 & 2.92 & 181413 & 1.32 & 0.59 \\
\hline$\alpha-5$-expansin & 3696569.2 .1 & AF332173 & 21885 & 2.40 & 1.39 & 13826 & 3.36 & 2.22 \\
\hline$\beta-5$ expansin & 2419405.2 .2 & AF332178 & 18565 & 2.39 & 2.17 & 17248 & 2.46 & 1.85 \\
\hline Xyloglucan endotransglycosylase (XTH) & 8010573.2 .1 & UI578I & 25201 & 2.32 & 1.68 & 21669 & 3.29 & 1.75 \\
\hline Endo-I.3-I.4- $\beta$-D-glucanase (ZmGnsNI) & 2192481.2 .2 & AF072326 & 27390 & 1.69 & 1.88 & 19511 & 3.03 & 2.29 \\
\hline Endoglucanase (endo-I.3- $\beta$-glucanase) & $37 \mid 3002.2 .1$ & AYI09289 & 44167 & 2.30 & 1.43 & 23557 & 3.66 & 2.08 \\
\hline Endoglucanase (endo-I.3- $\beta$-glucanase) & 2493751.2 .1 & AYIII608 & 36875 & 2.43 & 1.62 & 16100 & 4.90 & 3.06 \\
\hline Exoglucanase ( $\beta$-D-glucan exohydrolase II) & 2437739.2 .2 & AF064707 & 15307 & 2.39 & 1.60 & 15315 & 2.39 & 1.35 \\
\hline $\begin{array}{l}\text { Xyloglucan fucosyltransferase (AtFUTI } \\
\text { ortholog) }\end{array}$ & 3670899.2 .1 & AW287792 & 23393 & 1.84 & 1.77 & 16818 & 3.21 & 1.91 \\
\hline $\begin{array}{l}\text { Xyloglucan fucosyltransferase (AtFUT2 } \\
\text { ortholog) }\end{array}$ & $535 \mid 892.2 .1$ & AYII 2574 & 34273 & 2.02 & 1.27 & 21944 & 2.74 & 1.83 \\
\hline Pectate lyase & 3198766.2 .1 & CGI4082I & 35864 & 2.18 & 2.19 & 78008 & 2.17 & 2.87 \\
\hline Cellulose synthase (ZmCesA-I2) & QBS7b05.xg.2.1 & AY372246 & 45366 & 1.88 & 1.41 & 42685 & 2.14 & 1.54 \\
\hline Cellulose synthase (ZmCesA-9) & $244 \mid 542.2 .1$ & AF200533 & 14649 & 1.95 & 1.33 & 15755 & 2.22 & 1.58 \\
\hline
\end{tabular}

Normalized expression values are given for the F2 line and values for each mutant are expressed as ratios of signal intensity compared to normal plants. Genes were considered to be significantly differentially expressed when expression ratio values were lower than 0.5 or higher than 2.0 .

Values between the two thresholds are indicated in italics.

fibrils. The resulting network is considered to be the major tension-bearing structure in the primary wall [106]. Cleavage of xyloglucan chains by hydrolytic enzyme leads to rapid wall loosening, but also induces important risks of structural failure in the absence of concomitant reinforcement. XTH, capable of splitting and reconnecting xyloglucan molecules in a new position, help to satisfy the contradictory needs of growing and/or differentiating tissues [106]. Exo and endoglucanases are involved in specific degradation of cell wall $\beta$-glucans in auxin-mediated cell elongation $[107,108]$. ZmGnsN1, which was overexpressed in ear internodes of bm3 and AS225 plants, encodes an endo-1,3-1,4- $\beta$-D-glucanase first found in maize seedling growing tissues [107-109]. The two other over-expressed endoglucanases were ortholog to $\beta-1,3$ glucanase, which are also considered to be involved in hydrolysis of cell components and could be induced by hormone or wounding signals [110]. An exoglucanase was also overexpressed in $b m 3$ internodes which has been shown to preferentially hydrolyze the non-reducing terminal glucosyl residue from 1,3- $\beta$-D-glucans [111].

In maize, most hemicelluloses are arabinoxylans, with a few xyloglucans which are predominant in primary walls of dicotyledons. Xyloglucans have a backbone composed of $\beta$-1,4-glucose with up to $75 \%$ of the residues substituted with mono-, di-, or triglycosyl side chains. $\alpha-1,2-$ Xylosyl residues, linked to O6 of $\beta$-1,4-glucose, are partly further substituted by $\beta$-1,2-D-galactosyl. The latter can be further substituted by $\alpha$-1,2-linked fucosyl residues [112]. This last step is catalyzed by xyloglucan fucosyltransferases and two genes encoding members of this multigene family were over-expressed in ear internodes of COMT deficient plants.

Cell autolysis is a key event in tracheid formation. A maize gene ortholog to a pectate lyase (ZePel) expressed in the zinnia model system was found to be over-expressed in ear internodes of $b m 3$ and AS225 plants. ZePel was strongly expressed at a very early stage of tracheary element induction, and was related to the presence of auxin. Moreover, in young zinnia stems, ZePel expression was associated with vascular bundles [113]. The over-expression of this gene in $b m$ maize is likely an indication that this type of enzyme is involved in monocotyledon plant lignification. 
Two cellulose synthase genes were over-expressed in bm3 or AS225 internodes whereas no drastic modification was described in cellulose content in bm3 plants. Interestingly, ZmCesA-9 and ZmCesA-12 are respectively homolog to PtrCesA5 [114] and HvCesA8 [115] genes, highly expressed in developing xylem and stem undergoing significant secondary cell wall biosynthesis.

\section{Conclusion}

Disruption or down-regulation of COMT gene induced a correlative differential expression of only a few genes involved in the lignin pathway. These genes were all overexpressed, except for an under-expressed PAL gene. As a consequence, deregulation of maize COMT did not clearly highlight major co-regulation of lignin pathway genes. Similarly, no over-expressed phenylpropanoid related gene could explain that as much as $40 \%$ of S units were still present in bm3 lignins, with no COMT expression. Syringyl alcohol thus probably resulted from methylation by other OMT which were sufficiently available. One ZRP4-like OMT gene, which was shown to be overexpressed in maize bm3 plantlets [40] and which also had a tendency to be over-expressed in the bm3 ear internode, could be a candidate for the replacement of the lacking 5hydroxyconiferaldehyde methyltransferase activity.

Differential gene expressions in bm3 and/or AS225 internodes highlighted a probable disturbance in cell wall assembly and/or a possibly modified chronology of the different events leading to cell expansion and lignification with consequences far beyond the phenylpropanoid metabolism. The reduced availability of monolignols and $S$ units led to deeply different walls, with probably greater differences in carbohydrate composition than currently considered. During cell wall assembly, biosynthesis of phenylpropanoid, protein, and carbohydrate constituents appeared to be inter-dependent, and the deficiency in a key-enzyme of the lignin pathway had consequences on the expression of several genes involved in cell wall metabolism. Apart from a PRP gene in bm3 plants and a GRP gene in AS225 plants, all non-lignin-pathway differentially expressed genes were also over-expressed. Furthermore, the lower number of deregulated genes in AS225 plants than in bm 3 plants could result, in addition to the difference in genetic background of the two progenies, from the sclerenchyma-limited expression of the COMTantisens constructed gene.

The differential expression of genes in COMT-deficient plants is likely an indicator of their involvement in cell wall assembly, and some of these genes are probably new relevant targets for silage and biofuel maize breeding. While the transcription factors involved in regulation of lignin biosynthesis and deposition in maize are not yet clearly understood, the differential expression of one
ATHB-8 HD-zip III, two Argonaute, and one Shatterproof MAD-box orthologous genes between bm3 and normal plants could be the first evidence of their role in the cell wall metabolism. Similarly, maize COV1 ortholog could be assumed to be involved in lignified fiber tissue patterning. Finally, the comparison of gene expression in silking normal and $b m 3$ plants highlighted the possible involvement in the constitutive lignin pathway of not yet considered genes, such as ZRP4-like OMT.

\section{Methods}

\section{Plant material and RNA extraction}

The well known normal F2 line, originating from the Lacaune landrace, and its isogenic F2bm3 (7 backcrosses) were used with the COMT-AS (AS225) down regulated progeny previously described by Piquemal et al. [31] and Pichon et al. [116], which has only one backcross with the recurrent parent F2 (75 \% of F2 genetic background). The use of the Adh1 promoter directed COMT down-regulation specifically in sclerenchyma tissues, as shown by Maüle staining [31]. Hence, there was a different topology of modified tissues between COMT down-regulated plants and bm3 COMT-disrupted mutant plants. Plants were cropped in a greenhouse during the spring of 2004 at Lusignan (France), in pots with a mix of sand and compost, and were fed with usual nutritive solution.

Nine plants were harvested at silking stage, just before pollen shedding. The plants were divided into three pools of three plants each for transcriptome analysis. The first elongated basal internode and the internode below the node bearing the ear (ear internode) were sampled separately from each pool. Nodes and leaf sheaths were eliminated, and internodes were immediately frozen in liquid nitrogen. Total RNA was isolated from each set of frozen internodes ( $5 \mathrm{~g}$ ) by a method adapted from Ragueh et al. [117] and developed in Guillaumie et al. [43]. Internodes of grasses elongate in acropetal staggered succession, with an intercalary meristematic zone at the base of each internode which remains active until the final stage of elongation $[118,119]$. The basal internode is then physiologically older than the ear internode, and its lignification is more advanced than the more newly extended and fully lignifying ear internode [120-122].

\section{Histochemical Staining of Lignins}

Stem sections were cut with a vibratome from silking stage plants and silking + 30 days plants grown in the greenhouse. Wiesner and Maüle reactions were performed according to standard protocols [123]. Sections were observed using an inverted microscope (Leitz DMRIBE, Leica Microsystems, Wetzlar, Germany) with bright-field optics or epifluorescence illumination. Images were registered using a CCD camera (Color Coolview, Photonic Science, Milham, UK) and characterized through image 
analysis (Image PRO-Plus, Media Cybernetics, Silver Spring, MD). Wiesner reagent specifically reacts with cinnamaldehyde side chains in lignins and underlines the presence of lignins with a pink coloration. Lignified cell walls of xylem appear blue under UV illumination.

\section{Maize cell wall macro-array construction, membrane hybridization, and data analysis}

The maize cell wall macro-array, which consists of genespecific tags (GSTs) for 651 genes, was described in detail by Guillaumie et al. [43]. Spotted genes were chosen firstly as maize orthologs of genes expressed during secondary cell wall formation of zinnia (Zinnia elegans Jacq.) tracheary elements [80] and secondly from a keyword strategy developed from sequences previously described as involved in primary and secondary cell wall biosynthesis and assembly for all species throughout the plant kingdom. Maize orthologous genes were found from BLAST (blastn and tblastx) searches [124] performed against GenoPlante-Info databases [125].

Membrane hybridizations and data analyses were achieved according to a protocol adapted from Pesquet et al. [80] and developed in Guillaumie et al. [43]. Each GST was diluted to a final concentration of $0.5 \mathrm{mg} / \mathrm{ml}$ and then denatured in 50\% DMSO. Controls were added in separate 384-well plates. One plate included 384 TrisEDTA, pH 8.0 (blank background control). Another plate had 30 NPT II fragments (a positive hybridization control), 20 pBluescript plasmids (unspecific hybridization control), and 18 ubiquitin fragments (positive control). All fragments were spotted onto a $20 \times 20-\mathrm{cm}$ Nytran SuPerCharge nylon membrane (Schleicher and Schuell, Keene, NH, USA) using a BioGrid spotting robot (BioRobotics) in a $4 \times 4$ grid organization. Each gene was spotted twice in two different membrane grids corresponding to four replicates. cDNA probes were synthesized according to Guillaumie et al. [43] from $10 \mu \mathrm{g}$ of total RNA for each sample. Membranes were placed in a PhosphorImager cassette (Molecular Dynamics, Amersham- Pharmacia) for $72 \mathrm{~h}$ and scanned at $50 \mathrm{~mm} /$ pixel by a Storm 820 scanner (Amersham-Pharmacia).

Data analysis was performed according to Pesquet et al. [80] and Guillaumie et al. [43]. Macro-array gridding and gene expression levels were measured with ImageQuant 5.0 software (Molecular Dynamics, Amersham-Pharmacia) using $4 \times 4$ grids. Three independent hybridizations, each corresponding to one of the three groups of ear or basal internodes, were performed for normal, AS225 and bm3 plants. Reproducibility of raw signal intensity values on the membrane was first verified inside each grid and between the two grids for each investigated gene. According to Pesquet et al. [80] and Guillaumie et al. [43], two threshold values were thus defined so that $95 \%$ of the ratios between raw values of two replicates would be within the 0.5-2.0 interval. Aberrant values giving ratios outside of this interval were discarded. Normalization was performed based on the blank background, unspecific hybridization and positive controls (Tris-EDTA pH8, pBluescriptII, ubiquitin and kanamycin-NPTII). Macroarray reproducibility was further investigated by comparing normalized spot intensity values from the three independent hybridizations performed on three independent membranes. As was developed for reproducibility within the membrane, the investigations on the threshold values showed that more than $95 \%$ of the ratio values between independent hybridizations were confined within a twofold limit. Out of range values were discarded and $96-99 \%$ of the ratios between replicates were found between the two 0.5-2.0 threshold values. Expression data were estimated as the average of normalized intensity signal values of replicates, and comparisons between F2bm3 or AS225 with the normal F2 line were based on expression value ratios. According to Pesquet et al. [80] and Guillaumie et al. [43], genes with more than a twofold expression ratio in F2bm3 or AS225 compared with F2 were considered as differentially expressed genes. In addition, a variance analysis based on elementary normalized signal intensity values, followed by a bilateral Student $\mathrm{t}$ test (risk levels of $\mathrm{P}<0.05$ ), was performed. All genes that were considered differentially expressed were also validated by this statistical analysis. The normalized hybridization level under 3000 was similar to the macroarray blank value, and the minimal level of significant hybridizations was thus fixed to a normalized value equal to 6000 . For each differentially expressed gene, the mRNA number was searched using a BLAST (blastn) program against all available mRNA sequences in NCBI database.

In this investigation, only a subset of genes spotted on the MAIZEWALL macro-array was considered, in order to focus on lignin pathway, cell wall carbohydrate and cell wall protein genes and their transport and regulation factors. This subset thus comprised 105 phenylpropanoid genes, 44 transcription factor genes, 22 auxin related and tissue patterning genes, 33 transport and detoxification process associated genes, 18 cell wall protein genes, and 114 nucleotide sugar and cell wall carbohydrate genes. The exhaustive gene list has been given by Guillaumie et al. [43].

\section{RT-PCR}

Total RNA was isolated as described above. cDNA synthesis was conducted by incubating $1 \mu \mathrm{l}$ of DNase-treated total RNA $(1 \mu \mathrm{g} / \mu \mathrm{l})$ with $2 \mu \mathrm{l}$ of Oligo(dT)15 Primer (Promega, $500 \mu \mathrm{g} / \mathrm{ml}$ ) and $15 \mu \mathrm{l}$ of ultra-pure water for 5 min at $70^{\circ} \mathrm{C}$ and cooled down on ice for $5 \mathrm{~min}$. $5 \mu \mathrm{l}$ of Promega's MuMLVRT reverse transcriptase $5 \times$ buffer, 1.3 $\mu \mathrm{l}$ of $10 \mathrm{mM}$ dNTP and 200 units of MuMLV-RT reverse 
transcriptase (Promega) were added to the denatured RNA and incubated at $37^{\circ} \mathrm{C}$ for $1 \mathrm{~h}$. The reaction was stopped during $5 \mathrm{~min}$ at $70^{\circ} \mathrm{C}$ and then $5 \mathrm{~min}$ on ice. PCR was performed as follows: $95^{\circ} \mathrm{C}$ for $2 \mathrm{~min}$, X cycles $(15$ cycles for $18 \mathrm{~S}$ rRNA and 30 cycles for PAL, CCoAOMT3 and COMT) at $95^{\circ} \mathrm{C}$ for 30 s, $55^{\circ} \mathrm{C}-60^{\circ} \mathrm{C}$ for 30 s depending on primer couples, $72^{\circ} \mathrm{C}$ for $30 \mathrm{~s}$ and final extension 2 min in a total volume of $25 \mu \mathrm{l}$ with $12.5 \mu \mathrm{l}$ of $2 \times$ Master Mix PCR (Promega), $1 \mu \mathrm{l}$ of forward and reverse specific primers of each fragment (10 $\mu \mathrm{M}$ each), $9.5 \mu \mathrm{l}$ of ultrapure water and $1 \mu \mathrm{l}$ cDNA product. Resulting PCR products were analyzed by electrophoresis and stained with Etbr. The PCR primer combinations for each gene were as follows: PAL (2161072.2.1, L77912) forward 5'GGGGAGGAAATACGTGAAAA-3', reverse 5'-TTAGAAGGAATTGAGTACGC-3'; CCOAOMT3 (2591258.2.1, AY104670) forward 5'-CGTTCACGTCTGCCAGGT-3', reverse 5'-TTCACTCAAGCCCAGTTCG-3'; COMT (2192909.2.3, M73235): forward 5'-GCTTGCTTGGTCCTCGTATC-3', reverse 5'-TACTCGCACATGGCAGAGAC3'; 18S rRNA: forward 5'-CATGTCAAATTTCACTGCTTCATC-3', reverse 5'-TGACCACCCAGCCATCCTT-3'. All primers were synthesized by MWG-BIOTECH (Ebersberg, Germany).

\section{Abbreviations}

4CL: 4-coumarate:CoA ligase, 5-OH-G: 5-hydroxyguaiacyl, ABC: ATP-binding cassette, AGL: Agamous like, AGP: arabinogalactan protein, ALDH: aldehyde dehydrogenase, ARF: ADP- ribolysation factor, AS225: COMT antisens, bm: brown-midrib, C3'H: p-coumaroyl-shikimate/ quinate 3'-hydroxylases, $\mathrm{C} 4 \mathrm{H}$ : cinnamate 4-hydroxylase, CAD: cinnamyl alcohol dehydrogenase, CCoAOMT: caffeoyl-CoA O-methyltransferase, CCR: cinnamoyl-CoA reductase, COMT: caffeic acid O-methyltransferase, COV: CONTINUOUS VASCULAR RING, CHI: chalcone flavonone isomerase, DM: dry matter, $\mathrm{F} 5 \mathrm{H}$ : ferulate 5hydroxylase, FA: ferulic acid, G: guaiacyl, GEF: guanine nucleotide exchange factor, GlcA: glucuronic acid, GRP: glycine-rich protein, GST: glutathion S-transferase, GSTs: gene specific tags, H: p-hydroxyphenyl, HCT: hydroxycinnamoyl transferase, HD-Zip: Homeodomain-leucine zipper, HRGP: hydroxyproline-rich protein, MP: Monopteros, NDF: neutral detergent fiber, PAL: phenylalanine ammonia-lyase, pCA: $p$-coumaric, PID: PINOID, S: syringyl, PRP: proline-rich protein, SAD: sinapyl alcohol dehydrogenase, SHP: Shatterproof, TAL: tyrosine ammonia-lyase, UDP: uridine diphosphate, XTH: Xyloglucan endotransglycolase/hydrolase.

\section{Authors' contributions}

SG conducted the research, designed the experiments, analyzed the data and drafted the manuscript together with YB. DG and MP coordinated the construction of the MaizeWall macro-array and contributed to the experi- mental design of this work. OB contributed to acquisition of expression data. YB coordinated the project, and coordinated together with J-PM the Génoplante ZmS3P2 and B5 projects in which this work was managed. All authors read and approved the final manuscript.

\section{Acknowledgements}

Martial Briand, Dominique Denoue, Caroline Deswarte, Denise Gerentes, Yves Martinez and Hélène San Clemente are greatly thanked for their help in plant production and analysis. The management of the maize reference database by Corinne Melin was also greatly appreciated. This work was partly funded by Maize Génoplante projects and Sabine Guillaumie had a doctoral grant from INRA and the French Poitou-Charentes Land.

\section{References}

I. Barrière $Y$, Emile JC, Traineau R, Surault F, Briand M, Gallais A: Genetic variation for organic matter and cell wall digestibility in silage maize. Lessons from a 34-year long experiment with sheep in digestibility crates. Maydica 2004, 49: I I5-I 26.

2. Barrière $Y$, Ralph J, Méchin V, Guillaumie S, Grabber JH, Argillier $O$, Chabbert B, Lapierre C: Genetic and molecular basis of grass cell wall biosynthesis and degradability. II. Lessons from brown-midrib mutants. C R Biol 2004, 327:847-860.

3. Grabber JH, Ralph J, Lapierre C, Barrière Y: Genetic and molecular basis of grass cell-wall degradability. I. Lignin-cell wall matrix interactions. C R Biol 2004, 327:455-465.

4. Ralph J, Guillaumie S, Grabber JH, Lapierre C, Barrière Y: Genetic and molecular basis of grass cell-wall biosynthesis and degradability. III. Towards a forage grass ideotype. C $R$ Biol 2004, 327:467-479.

5. Kuc J, Nelson OE: The abnormal lignins produced by the brown-midrib mutants of maize. Arch Biochem Biophys 1964, 105:103-113.

6. Gee MS, Nelson $\mathrm{OE}, \mathrm{Kuc}$ J: Abnormal lignins produced by the brown-midrib mutants of maize. Il. Comparative studies on normal and brown-midrib-I dimethylformamide lignins. Arch Biochem Biophys 1968, 1 23:403-408.

7. Kuc J, Nelson OE, Flagnan P: Degradation of abnormal lignins in the brown midrib mutants and double mutants of maize. Phytochemistry 1968, 7:1345-1346.

8. Barnes RF, Muller LD, Bauman LF, Colenbrander VF: In vitro dry matter disappearance of brown midrib mutants of maize (Zea mays L.). J Anim Sci I 97I, 33:88I-884.

9. Lechtenberg V, Muller L, Bauman L, Rhykerd C, Barnes R: Laboratory and in vitro evaluation of inbred and $F 2$ populations of brown midrib mutants of Zea mays L. Agron J 1972, 64:657-660.

10. Colenbrander VF, Lechtenberg VL, Bauman LF, Muller LD, Rhykerd CL: Nutritive value of brown midrib corn silage. J Anim Sci 1972, 35: I I I3.

II. Colenbrander VF, Lechtenberg VL, Bauman LF: Digestibility and feeding value of brown midrib corn stover silage. J Anim Sci 1973, 37:294-295.

12. Colenbrander VF, Lechtenberg VL, Bauman LF: Feeding value of low lignin corn silage. J Anim Sci 1975, 41:332-333.

13. Barrière $Y$, Guillet $C$, Goffner D, Pichon M: Genetic variation and breeding strategies for improved cell wall digestibility in annual forage crops. A review. Anim Res 2003, 52:193-228.

14. Barriere $Y$ : Breeding for silage quality traits in cereals. In Cereal Breeding Edited by: Carena MJ. NY: Springer; 2008 in press.

15. Barrière Y, Goncalves G, Emile J, Lefevre B: Higher intake of DK265 corn silage by dairy cattle. J Dairy Sci 2004, 87:|439-| 445.

16. Oba M, Allen M: Effects of brown midrib 3 mutation in corn silage on productivity of dairy cows fed two concentrations of dietary neutral detergent fiber: 3 . Digestibility and microbial efficiency. J Dairy Sci 2000, 83: 1350-1358.

17. Ballard CS, Thomas ED, Tsang DS, Mandebvu P, Sniffen CJ, Endres MI, Carter MP: Effect of corn silage hybrid on dry matter yield, nutrient composition, in vitro digestion, intake by dairy heifers, and milk production by dairy cows. J Dairy Sci 200I, 84:442-452. 
18. Schwab EC, Shaver RD, Shinners KJ, Lauer JG, Coors JG: Processing and chop length effects in brown-midrib corn silage on intake, digestion, and milk production by dairy cows. J Dairy Sci 2002, 85:613-623.

19. Cherney J, Cherney D, Akin D, Axtell J: Potential of brown-midrib, low-lignin mutants for improving forage quality. Adv Agron |99|, 46: I57-198.

20. Barrière $Y$, Argillier $O$ : Brown-midrib genes of maize - $A$ review. Agronomie 1993, 13:865-876.

21. Jung HG, Deetz DA: Cell wall lignification and degradability. In Forage cell wall structure and digestibility Madison, USA; 1993:315-345.

22. Lapierre C, Tollier MT, Monties B: A new type of constitutive unit in lignins from the corn bm3 mutant. C R Acad Sci 1988, ser.3:723-728.

23. Ralph J, Hatfield RD, Quideau S, Helm RF, Grabber JH, Jung HJG: Pathway of p-coumaric acid incorporation into maize lignin as revealed by NMR. J Am Chem Soc 1994, I I 6:9448-9456.

24. Grabber JH, Quideau S, Ralph J: p-Coumaroylated syringyl units in maize lignin: Implications for beta-ether cleavage by thioacidolysis. Phytochemistry 1996, 43: I 189-1194.

25. Lu FC, Ralph J: Detection and determination of p-coumaroylated units in lignins. J Agric Food Chem 1999, 47:1988-1992

26. Chabbert B, Tollier MT, Monties B, Barrière Y, Argillier O: Biological variability in lignification of maize - expression of the brown midrib bm $\mathbf{3}$ mutation in $\mathbf{3}$ maize cultivars. J Sci Food Agric 1994, 64:349-355.

27. Marita JM, Vermerris W, Ralph J, Hatfield RD: Variations in the cell wall composition of maize brown midrib mutants. J Agric Food Chem 2003, 51:|3|3-|32|.

28. Grand C, Parmentier P, Boudet A, Boudet A: Comparison of lignins and of enzymes involved in lignification in normal and brown midrib (bm3) mutant corn seedlings. Physiol Veg 1985, 23:905-911.

29. Vignols F, Rigau J, Torres MA, Capellades M, Puigdomenech P: The brown midrib3 (bm3) mutation in maize occurs in the gene encoding caffeic acid O-methyltransferase. Plant Cell 1995, 7:407-416

30. Morrow SL, Mascia P, Self KA, Altschuler M: Molecular characterization of a brown midrib3 deletion mutation in maize. Mol Breed 1997, 3:35I-357.

31. Piquemal J, Chamayou S, Nadaud I, Beckert M, Barrière Y, Mila I, Lapierre C, Rigau J, Puigdomenech P, Jauneau A, Digonnet C, Boudet AM, Goffner D, Pichon M: Down-regulation of caffeic acid O-methyltransferase in maize revisited using a transgenic approach. Plant Physiol 2002, 130: 1675-I685.

32. He X, Hall MB, Gallo-Meagher M, Smith RL: Improvement of forage quality by down-regulation of maize O-methyltransferase. Crop Sci 2003, 43:2240-225I.

33. Chapple CCS, Vogt T, Ellis BE, Somerville CR: An Arabidopsis mutant defective in the general phenylpropanoid pathway. Plant Cell 1992, 4: I4I3-1424.

34. Jung HJG, Ni WT, Chapple CCS, Meyer K: Impact of lignin composition on cell-wall degradability in an Arabidopsis mutant. J Sci Food Agric 1999, 79:922-928.

35. Goujon T, Sibout R, Maba B, Nussaume L, Bechtold N, Lu F, Ralph J Pollet B, Mila I, Charpentier JP, Barrière Y, Lapierre C, Jouanin L: A new Arabidopsis thaliana mutant deficient in the expression of O-methyltransferase impacts lignins and sinapoyl esters. Plant Mol Biol 2003, 5 I:973-989.

36. Barriere $Y$, Riboulet $C$, Méchin V, Maltese S, Pichon M, Cardinal AJ, Lapierre C, Lübberstedt T, Martinant JP: Genetics and genomics of lignification in grass cell walls based on maize as a model system. Genes, Genomes and Genomics 2007, I: 133-156.

37. Nair RB, Bastress KL, Ruegger MO, Denault JW, Chapple C: The Arabidopsis thaliana reduced epidermal fluorescence I gene encodes an aldehyde dehydrogenase involved in ferulic acid and sinapic acid biosynthesis. Plant Cell 2004, I 6:544-554.

38. Marita JM, Ralph J, Hatfield RD, Guo DJ, Chen F, Dixon RA: Structural and compositional modifications in lignin of transgenic alfalfa down-regulated in caffeic acid 3-O-methyltransferase and caffeoyl coenzyme A 3-O-methyltransferase. Phytochemistry 2003, 62:53-65.

39. Grenet E, Barry P: Microbial degradation of normal maize and bm3 maize in the rumen observed by scanning electron microscopy. J Sci Food Agric 199I, 54:199-210.
40. Guillaumie S, Pichon M, Martinant JP, Bosio M, Goffner D, Barrière Y: Differential expression of phenylpropanoid and related genes in brown-midrib $\mathrm{bml}, \mathrm{bm} 2, \mathrm{bm} 3$, and $\mathrm{bm} 4$ young nearisogenic maize plants. Planta 2007, 226:235-250.

4I. Shi C, Koch G, Ouzunova M, Wenzel G, Zein I, Lübberstedt T: Comparison of maize brown-midrib isogenic lines by cellular UV. microspectrophotometry and comparative transcript profiling. Plant Mol Biol 2006, 62:697-7I4

42. Shi C, Uzarowska A, Ouzunova M, Landbeck M, Wenzel G, Lübberstedt $\mathrm{T}$ : Identification of candidate genes associated with cell wall digestibility and eQTL (expression quantitative trait loci) analysis in a Flint $\times$ Flint maize recombinant inbred line population. BMC Genomics 2007, 8:22.

43. Guillaumie S, San-Clemente H, Deswarte C, Martinez Y, Lapierre $C$, Murigneux A, Barrière $Y$, Pichon M, Goffner D: MAIZEWALL. Database and developmental gene expression profiling of cell wall biosynthesis and assembly in maize. Plant Physiol 2007 , 143:339-363.

44. Civardi L, Rigau J, Puigdomenech P: Nucleotide sequence of two cDNAs coding for caffeoyl-coenzyme A O-methyltransferase and their expression in maize (Accession Nos.AJ242980 and AJ24298 I). Plant Physiol 1999, 1 20:1206.

45. Dence CW, Lin SY: The determination of lignin. In Methods in Lignin Chemistry Edited by: Lin SY, Dence CW. Berlin, Germany: Springer-Verlag; |992:33-61.

46. Struik P: Physiology of forage maize (Zea mays L.) in relation to its production and quality. In Ph Dissertation Agricultural University, $6700 \mathrm{GW}$ Wageningen, Netherlands; 1983:252.

47. Martz F, Maury S, Pincon G, Legrand M: cDNA cloning, substrate specificity and expression study of tobacco caffeoyl-CoA 3O-methyltransferase, a lignin biosynthetic enzyme. Plant Mol Biol 1998, 36:427-437.

48. Meng H, Campbell WH: Substrate profiles and expression of caffeoyl coenzyme $A$ and caffeic acid O-methyltransferases in secondary xylem of aspen during seasonal development. Plant Mol Biol 1998, 38:5 I3-520.

49. Parvathi K, Chen F, Guo DJ, Blount JW, Dixon RA: Substrate preferences of $O$-methyltransferases in alfalfa suggest new pathways for 3-O-methylation of monolignols. Plant J 200I, 25:193-202.

50. Held BM, Wang HQ, John I, Wurtele ES, Colbert JT: An messengerRNA putatively coding for an O-methyltransferase accumulates preferentially in maize roots and is located predominantly in the region of the endodermis. Plant Physiol 1993, 102:1001-1008.

5I. Mobley EM, Kunkel BN, Keith B: Identification, characterization and comparative analysis of a novel chorismate mutase gene in Arabidopsis thaliana. Gene 1999, 240:1 I5-123.

52. Ehlting J, Mattheus N, Aeschliman DS, Li EY, Hamberger B, Cullis IF, Zhuang J, Kaneda M, Mansfield SD, Samuels L, Ritland K, Ellis BE, Bohlmann J, Douglas C): Global transcript profiling of primary stems from Arabidopsis thaliana identifies candidate genes for missing links in lignin biosynthesis and transcriptional regulators of fiber differentiation. Plant J 2005, 42:6I8-640.

53. Fischer RS, Zhao GS, Jensen RA: Cloning, sequencing, and expression of the P-protein gene (Phea) of Pseudomonas stutzeri in Escherichia coli - Implications for evolutionary relationships in phenylalanine biosynthesis. Journal of General Microbiology |99|, |37:|293-130|.

54. de Obeso M, Caparros-Ruiz D, Vignols F, Puigdomenech P, Rigau J: Characterisation of maize peroxidases having differential patterns of mRNA accumulation in relation to lignifying tissues. Gene 2003, 309:23-33.

55. Ranocha $P$, Chabannes M, Chamayou S, Danoun S, Jauneau A, Boudet AM, Goffner D: Laccase down-regulation causes alterations in phenolic metabolism and cell wall structure in poplar. Plant Physiol 2002, I 29: | $45-155$.

56. Kirch HH, Bartels D, Wei YL, Schnable PS, Wood AJ: The ALDH gene superfamily of Arabidopsis. Trends Plant Sci 2004 9:37I-377.

57. Kirch HH, Schlingensiepen S, Kotchoni S, Sunkar R, Bartels D: Detailed expression analysis of selected genes of the aldehyde dehydrogenase (ALDH) gene superfamily in Arabidopsis thaliana. Plant Mol Biol 2005, 57:3 15-332. 
58. Grotewold E, Peterson T: Isolation and characterization of a maize gene encoding chalcone flavonone isomerase. Mol Gen Genet 1994, 242: I-8.

59. Kim S, Jones R, Yoo KS, Pike LM: Gold color in onions (Allium cepa): a natural mutation of the chalcone isomerase gene resulting in a premature stop codon. Mol Genet Genomics 2004, 272:41।-419.

60. Himi E, Noda K: Red grain colour gene (R) of wheat is a Mybtype transcription factor. Euphytica 2005, I 43:239-242.

61. Baima S, Nobili F, Sessa G, Lucchetti S, Ruberti I, Morelli G: The expression of the Athb-8 homeobox gene is restricted to provascular cells in Arabidopsis thaliana. Development 1995, I 2 I:4|7|-4|82.

62. Baima S, Possenti M, Matteucci A, Wisman E, Altamura MM, Ruberti I, Morelli G: The Arabidopsis ATHB-8 HD-zip protein acts as a differentiation-promoting transcription factor of the vascular meristems. Plant Physiol 200I, I 26:643-655.

63. Rhoades MW, Reinhart BJ, Lim LP, Burge CB, Bartel B, Bartel DP. Prediction of plant microRNA targets. Cell 2002, I I 0:5 I 3-520.

64. Bowman JL: Class III HD-Zip gene regulation, the golden fleece of ARGONAUTE activity? Bioessays 2004, 26:938-942.

65. Juarez MT, Kui JS, Thomas J, Heller BA, Timmermans MCP: microRNA-mediated repression of rolled leafI specifies maize leaf polarity. Nature 2004, 428:84-88.

66. Liljegren SJ, Ditta GS, Eshed HY, Savidge B, Bowman JL, Yanofsky MF: SHATTERPROOF MADS-box genes control seed dispersal in Arabidopsis. Nature 2000, 404:766-770.

67. Yanofsky M, Ma H, Bowman J, Drews G, Feldmann K, Meyerowitz E: The protein encoded by the Arabidopsis homeotic gene agamous resembles transcription factors. Nature 1990, 346:35-39.

68. Ma H, Yanofsky MF, Meyerowitz EM: Agll-Agl6, an Arabidopsis gene family with similarity to floral homeotic and transcription factor genes. Genes \& Development I99I, 5:484-495.

69. Benjamins R, Quint A, Weijers D, Hooykaas P, Offringa R: The PINOID protein kinase regulates organ development in Arabidopsis by enhancing polar auxin transport. Development 200I, I 28:4057-4067.

70. Friml J, Palme K: Polar auxin transport - old questions and new concepts? Plant Mol Biol 2002, 49:273-284.

7I. Friml J, Yang X, Michniewicz M, Weijers D, Quint A, Tietz O, Benjamins R, Ouwerkerk PBF, Ljung K, Sandberg G, Hooykaas PJJ, Palme K, Offringa R: A PINOID-dependent binary switch in apicalbasal PIN polar targeting directs auxin efflux. Science 2004, 306:862-865.

72. Shevell DE, Kunkel T, Chua NH: Cell wall alterations in the Arabidopsis emb30 mutant. Plant Cell 2000, I 2:2047-2059.

73. Koizumi K, Naramoto S, Sawa S, Yahara N, Ueda T, Nakano A, Sugiyama $M$, Fukuda $\mathrm{H}$ : VAN3 ARF-GAP-mediated vesicle transport is involved in leaf vascular network formation. Development 2005, 132:1699-1711.

74. Geldner N, Anders N, Wolters H, Keicher J, Kornberger W, Muller P, Delbarre A, Ueda T, Nakano A, Jurgens G: The Arabidopsis GNOM ARF-GEF mediates endosomal recycling, auxin transport, and auxin-dependent plant growth. Cell 2003, I I 2:219-230.

75. Hardtke CS, Berleth T: The Arabidopsis gene MONOPTEROS encodes a transcription factor mediating embryo axis formation and vascular development. EMBO j I998, I 7: | 405- |4 | I.

76. Hardtke CS, Ckurshumova W, Vidaurre DP, Singh SA, Stamatiou G Tiwari SB, Hagen G, Guilfoyle T], Berleth T: Overlapping and nonredundant functions of the Arabidopsis auxin response factors MONOPTEROS and NONPHOTOTROPIC HYPOCOTYL 4. Development 2004, I 3 I : I089-I I 00.

77. Parker G, Schofield R, Sundberg B, Turner S: Isolation of COVI, a gene involved in the regulation of vascular patterning in the stem of Arabidopsis. Development 2003, I 30:2 I 39-2I 48.

78. Yamagata $H$, Masuzawa $T$, Nagaoka $Y$, Ohnishi T, Iwasaki T: Cucumisin, a serine protease from melon fruits, shares structural homology with subtilisin and is generated from a large precursor. Journal of Biological Chemistry 1994, 269:32725-32731.

79. Schaller A: A cut above the rest: the regulatory function of plant proteases. Planta 2004, 220:183-197.

80. Pesquet E, Ranocha P, Legay S, Digonnet C, Barbier O, Pichon M, Goffner D: Novel markers of xylogenesis in zinnia are differentially regulated by auxin and cytokinin. Plant Physiol 2005, 139:1821-1839.
81. Zhao CS, Johnson BJ, Kositsup B, Beers EP: Exploiting secondary growth in Arabidopsis. Construction of xylem and bark cDNA libraries and cloning of three xylem endopeptidases. Plant Physiol 2000, I 23: I 185-I196.

82. Sanchez-Fernandez R, Davies TGE, Coleman JOD, Rea PA: The Arabidopsis thaliana $A B C$ protein superfamily, a complete inventory. J Bio Chem 200I, 276:3023 I-30244.

83. Yazaki K: Transporters of secondary metabolites. Curr Opin Plant Biol 2005, 8:30I-307.

84. Samuels AL, Rensing KH, Douglas CJ, Mansfield SD, Dharmawardhana $\mathrm{DP}$, Ellis BE: Cellular machinery of wood production: differentiation of secondary xylem in Pinus contorta var. latifolia. Planta 2002, 2 I 6:72-82.

85. Marrs KA, Alfenito MR, Lloyd AM, Walbot V: A Glutathione-STransferase involved in vacuolar transfer encoded by the maize gene Bronze2. Nature 1995, 375:397-400.

86. Pairoba CF, Walbot V: Post-transcriptional regulation of expression of the Bronze2 gene of Zea mays L. Plant Mol Biol 2003, 53:75-86.

87. McGonigle B, Keeler SJ, Lan SMC, Koeppe MK, O'Keefe DP: A genomics approach to the comprehensive analysis of the glutathione S-transferase gene family in soybean and maize. Plant Physiol 2000, I 24:1105-1120.

88. Goodman CD, Casati P, Walbot V: A multidrug resistance-associated protein involved in anthocyanin transport in Zea mays. Plant Cell 2004, 16:1812-1826.

89. Schwab W: Metabolome diversity: too few genes, too many metabolites? Phytochemistry 2003, 62:837-849.

90. Ford CM, Boss PK, Hoj PB: Cloning and characterization of Vitis vinifera UDP-glucose : flavonoid 3-O-glucosyltransferase, a homologue of the enzyme encoded by the maize Bronze-I locus that may primarily serve to glucosylate anthocyanidins in vivo. J Biol Chem 1998, 273(1 5):9224-9233.

91. Schultz C, Gilson P, Oxley D, Youl J, Bacic A: GPI-anchors on arabinogalactan-proteins: implications for signalling in plants. Trends Plant Sci 1998, 3:426-43I.

92. Sun WX, Xu JF, Yang J, Kieliszewski MJ, Showalter AM: The lysinerich arabinogalactan-protein subfamily in Arabidopsis: Gene expression, glycoprotein purification and biochemical characterization. Plant Cell Physiol 2005, 46:975-984.

93. Yang SH, Wang HY, Sathyan P, Stasolla C, Loopstra CA: Real-time RT-PCR analysis of loblolly pine (Pinus taeda) arabinogalactan-protein and arabinogalactan-protein-like genes. Physiol Plant 2005, 124:91-106.

94. Zhang $Y$, Brown G, Whetten R, Loopstra CA, Neale D, Kieliszewsk $M J$, Sederoff RR: An arabinogalactan protein associated with secondary cell wall formation in differentiating xylem of loblolly pine. Plant Mol Biol 2003, 52:91-102.

95. Sachetto-Martins G, Franco LO, de Oliveira DE: Plant glycine-rich proteins: a family or just proteins with a common motif? Biochim Biophys Acta 2000, I 492(I): I-I4.

96. Ringli C, Keller B, Ryser U: Glycine-rich proteins as structural components of plant cell walls. Cell Mol Life Sci 200I, 58: $|430-| 44 \mid$.

97. Liu ZZ, Wang JL, Huang $X, X u$ WH, Liu ZM, Fang RX: The promoter of a rice glycine-rich protein gene, Osgrp-2, confers vascular-specific expression in transgenic plants. Planta 2003, 21 6:824-833

98. Cassab GI: Plant cell wall proteins. Annu Rev Plant Physiol Plant Mol Biol 1998, 49:28I-309.

99. Vignols F, Jose-Estanyol M, Caparros-Ruiz D, Rigau J, Puigdomenech $P$ : Involvement of a maize proline-rich protein in secondary cell wall formation as deduced from its specific mRNA localization. Plant Mol Biol 1999, 39:945-952.

100. Reiter WD, Vanzin GF: Molecular genetics of nucleotide sugar interconversion pathways in plants. Plant Mol Biol 200I, 47:95-II3.

I0I. Kawakita M, Ishida N, Miura N, Sun-Wada GH, Yoshioka S: Nucleotide sugar transporters: Elucidation of their molecular identity and its implication for future studies. | Biochem 1998 , I 23:777-785

102. Gibeaut DM: Nucleotide sugars and glycosyltransferases for synthesis of cell wall matrix polysaccharides. Plant Physiol Biochem 2000, 38:69-80.

103. Dennis DT, Blakeley SD: Carbohydrate metabolism. In Biochemistry and Molecular Biology of Plants Edited by: Buchanan B, Gruissem 
W, Jones RL. Rockville, MD: American Society of Plant Biologist; 2000:630-675

104. Cosgrove DJ: Expansive growth of plant cell walls. Plant Physiol Biochem 2000, 38:109-124.

105. Li Y, Jones L, McQueen-Mason S: Expansins and cell growth. Curr Opin Plant Biol 2003, 6:603-6I0.

106. Rose JKC, Braam J, Fry SC, Nishitani K: The XTH family of enzymes involved in xyloglucan endotransglucosylation and endohydrolysis: Current perspectives and a new unifying nomenclature. Plant Cell Physiol 2002, 43: | 42 I-| 435.

107. Inouhe M, Inada G, Thomas BR, Nevins DJ: Cell wall autolytic activities and distribution of cell wall glucanases in Zea mays L. seedlings. Int J Biol Macromol 2000, 27:15I-I56.

108. Inouhe M, Hayashi K, Thomas BR, Nevins DJ: Exo- and endoglucanases of maize coleoptile cell walls: their interaction and possible regulation. Int J Biol Macromol 2000, 27:157-162.

109. Thomas BR, Inouhe M, Simmons CR, Nevins DJ: Endo- I,3; I,4-betaglucanase from coleoptiles of rice and maize: role in the regulation of plant growth. Int J Biol Macromol 2000, 27:145-I49.

1 10. Wu CT, Leubner-Metzger G, Meins F, Bradford KJ: Class I beta- I,3glucanase and chitinase are expressed in the micropylar endosperm of tomato seeds prior to radicle emergence. Plant Physiol 200I, I 26: I 299-I3। 3.

III. Kim JB, Olek AT, Carpita NC: Cell wall and membrane-associated exo-beta-D-glucanases from developing maize seedlings. Plant Physiol 2000, I 23:47 I-485.

II2. Scheible WR, Pauly M: Glycosyltransferases and cell wall biosynthesis: novel players and insights. Curr Opin Plant Biol 2004, 7:285-295.

113. Domingo C, Roberts K, Stacey NJ, Connerton I, Ruiz-Teran F, Mccann MC: A pectate lyase from Zinnia elegans is auxin inducible. Plant $j$ 1998, 13:17-28.

I14. Kalluri UC, Joshi CP: Isolation and characterization of a new, full-length cellulose synthase cDNA, PtrCesA5 from developing xylem of aspen trees. J Exp Bot 2003, 54:2187-2। 88.

115. Burton RA, Shirley NJ, King BJ, Harvey AJ, Fincher GB: The CesA gene family of barley. Quantitative analysis of transcripts reveals two groups of co-expressed genes. Plant Physiol 2004, 134:224-236.

116. Pichon M, Deswartes C, Gerentes D, Guillaumie S, Lapierre C, Toppan $A$, Barrière $Y$, Goffner $D$ : Variation in lignin and cell wall digestibility in caffeic acid O-methyltransferase down-regulated maize half-sib progenies in field experiments. Mol Breed 2006, I8:253-26I.

117. Ragueh F, Lescure N, Roby D, Marco Y: Gene expression in Nicotiana tabacum in response to compatible and incompatible isolates of Pseudomonas solanacearum. Physiol Mol Plant Pathol 1989, 35:23-33.

II8. Cherney J, Volenec J, Brown G: Synthesis of cell wall components in maize internodes. Edited by: Desroches R. Nice, France; 1989:759-760.

119. Scobbie L, Russell W, Provan GJ, Chesson A: The newly extended maize internode - A model for the study of secondary cellwall formation and consequences for digestibility. I Sci Food Agric 1993, $61: 217-225$.

120. Morrison TA, Buxton DR: Activity of phenylalanine ammonialyase, tyrosine ammonia-lyase, and cinnamyl alcohol-dehydrogenase in the maize stalk. Crop Sci 1993, 33:1264-1268.

I2I. Morrison T, Kessler J, Buxton D: Maize internode elongation patterns. Crop Sci 1994, 34: $1055-1060$.

122. Morrison TA, Jung HG, Buxton DR, Hatfield RD: Cell-wall composition of maize internodes of varying maturity. Crop Sci 1998 38:455-460.

123. Nakano J, Meshitsuka G: The detection of lignin. In Methods in Lignin Chemistry Edited by: Dence CW, Lin SY. Berlin: Springer-Verlag; 1992:23-61.

124. Altschul SF, Madden TL, Schaffer AA, Zhang JH, Zhang Z, Miller W, Lipman DJ: Gapped BLAST and PSI-BLAST: a new generation of protein database search programs. Nucleic Acids Res 1997 25:3389-3402

125. Samson D, Legeai F, Karsenty E, Reboux S, Veyrieras JB, Just JB, Barillot E: GénoPlante-Info (GPI): a collection of databases and bioinformatics resources for plant genomics. Nucleic Acids Research 1997, 31 : 179-182.
Publish with Biomed Central and every scientist can read your work free of charge

"BioMed Central will be the most significant development for disseminating the results of biomedical research in our lifetime. "

Sir Paul Nurse, Cancer Research UK

Your research papers will be:

- available free of charge to the entire biomedical community

- peer reviewed and published immediately upon acceptance

- cited in PubMed and archived on PubMed Central

- yours - you keep the copyright
BioMedcentral 